Ekspansi: Jurnal Ekonomi, Keuangan, Perbankan dan Akuntansi

ISSN (Online): 2580-7668 ISSN (Print): 2085-5230

Vol. 13, No. 1 (Mei 2021), Hal. 1 - 14

\title{
PENGARUH ETIKA PROFESI DAN KOMPETENSI TERHADAP PENGAMBILAN KEPUTUSAN ETIS KONSULTAN PAJAK DI SURABAYA
}

\author{
Rima Sundari ${ }^{1}$, Rukmi Juwita ${ }^{2}$, Y. Casmadi ${ }^{3}$, Arief Syafrizal ${ }^{4}$ \\ ${ }^{1,2}$ Program Studi Diploma 4 Akuntansi Keuangan-Politeknik Pos Indonesia, Bandung, \\ Indonesia \\ Email Korespondensi: rimasundari@poltekpos.ac.id
}

\begin{abstract}
Tax Consultant is a person or entity who provides tax consulting services to taxpayers in order to fulfill their tax obligations and rights. This study aims to determine the effect of professional ethics and competence on ethical decision making of Tax Consultants. This research was conducted because there are not a few irregularities or fraud committed by Tax Consultants. This research method is associative quantitative research with simple random sampling. The research population is a Tax Consultant in Surabaya. The analytical tools used are normality, validity, reliability, t-test, f-test product moment correlation, multiple correlation, coefficient of determination and multiple linear regression. The results showed that professional ethics and competence have a positive influence on ethical decision making of Tax Consultants in Surabaya, either partially or simultaneously.
\end{abstract}

Keywords: Tax Consultant, Professional Ethics, Competence, Decision Making

Abstrak: Konsultan Pajak adalah orang atau badan yang memberikan jasa konsultasi perpajakan kepada wajib pajak dalam rangka memenuhi kewajiban serta hak perpajakannya. Penelitian ini bertujuan untuk mengetahui pengaruh etika profesi dan kompetensi terhadap pengambilan keputusan etis Konsultan Pajak. Penelitian ini dilakukan karena tidak sedikit penyimpangan atau fraud yang dilakukan oleh Konsultan Pajak. Metode penelitian ini berupa penelitian kuantitatif asosiatif dengan pengambilan sampel simple random sampling. Populasi penelitian adalah Konsultan Pajak di Surabaya. Alat analisis yang digunakan uji normalitas, validitas, reliabilitas, uji t, uji f korelasi product moment, korelasi berganda, koefisien determinasi dan regresi linear berganda. Hasil penelitian menunjukkan bahwa etika profesi dan kompetensi memiliki pengaruh positif terhadap pengambilan keputusan etis Konsultan Pajak di Surabaya baik secara parsial maupun stimultan.

Kata Kunci: Konsultan Pajak, Etika Profesi, Kompetensi, Pengambilan Keputusan Etis. 


\section{PENDAHULUAN}

Pertumbuhan penerimaan pajak pada enam tahun terakhir mengalami fluktuasi yang cenderung menunjukan adanya peningkatan dari tahun ke tahun. Ini menandakan bahwa penerimaan pajak migas dan pajak non migas menjadi pendapatan terbesar Negara Indonesia. Peningkatan penerimaan Pajak ini menunjukan tingginya kepatuhan dari para wajib pajak dalam melaksankan kewajiban perpajakannya. Dalam APBN Kita (2021) yang diterbitkan oleh kemenkeu.go,id dikatakan bahwa jumlah Surat Pemberitahuan (SPT) Tahunan PPh yang disampaikan oleh wajib pajak pada tahun 2020 adalah sebanyak 14,76 juta SPT atau sebesar 78\% dari jumlah wajib pajak yang wajib melaporkan SPT, angka ini menunjukan peningkatan dari tahun sebelumnya yaitu hanya sebesar $73 \%$.

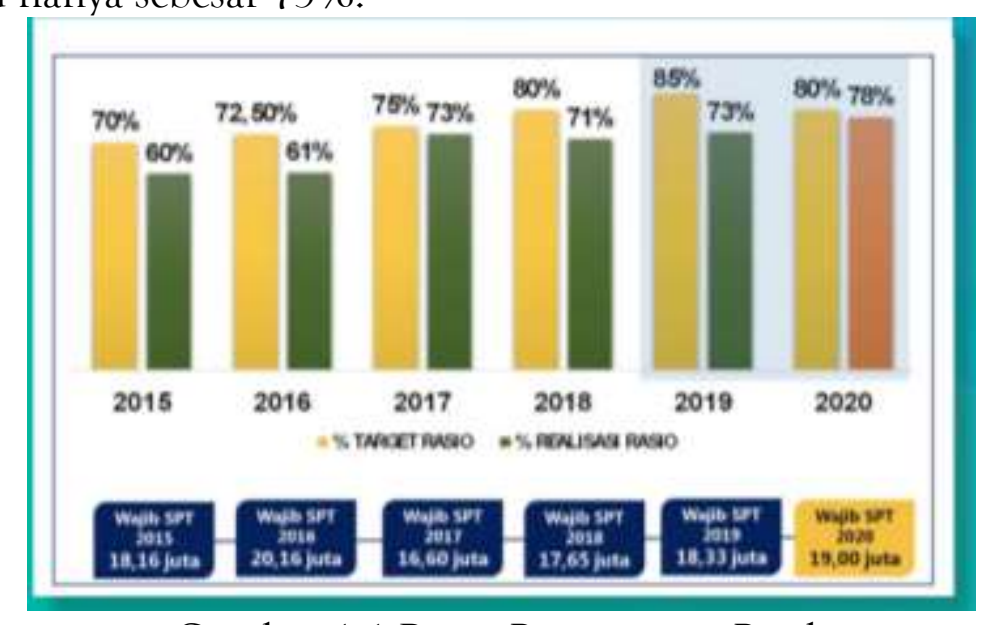

Gambar 1.1 Rasio Penerimaan Pajak

Sumber : www.kemenkeu.go.id (2021)

Sebelum melakukan proses pelaporan SPT, wajib pajak melakukan proses menghitung jumlah pajak yang terutang dan membayar pajak sesuai dengan perhitungan perpajakan. Sistem pemungutan pajak di Indonesia salah satunya adalah sistem penilaian sendiri (self assessment system), yaitu jumlah pajak yang harus dibayar oleh wajib pajak ditentukan oleh wajib pajak itu sendiri. Peraturan Menteri Keuangan Republik Indonesia nomor 111/PMK.03/2014, menyatakan bahwa "Konsultan Pajak adalah orang yang memberikan jasa konsultasi perpajakan kepada wajib pajak dalam rangka melaksanakan kewajiban dan hak perpajakannya sesuai dengan peraturan perundang-undangan perpajakan”. Konsultan Pajak sendiri mengalami dilema pengambilan keputusan etis karena satu sisi Konsultan Pajak memiliki kepentingan meminimalkan beban pajak dan di sisi lain Konsultan Pajak memiliki kepentingan dalam meningkatkan jumlah penerimaan pajak dan wajib pajak untuk membayar pajak dengan benar dan sesuai dengan peraturan perpajakan.

Dalam laporan Siwy (2015) di mana dalam wawancaranya kepada beberapa Konsultan Pajak, Konsultan Pajak pernah diminta untuk merekayasa laporan pajak, bahkan Konsultan Pajak X menyimpang atau salah dalam mengambil keputusan karena konsultan X menerima tawaran dari klien untuk merekayasa laporan pajak kliennya. Fenomena ini diperkuat dengan adanya berita yang diterbitkan pada laman 
Kompas.com (2018) bahwa ada seorang Konsultan Pajak dari kantor pajak yang menerima suap dari wajib pajak.

Pemberitaan mengenai kasus penyelewengan wewenang konsultan pajak ini juga di beritakan oleh portal DetikNews (2019) di mana seorang Konsultan Pajak melakukan penyelewengan pajak sebesar Rp.700.000.000 dengan cara memalsukan faktur pajak untuk memperkecil pajak pada perusahaan kliennya dan mengambil keuntungan atas selisih nilai pajak tersebut. Fenomena mengenai kecurangan konsultan pajak pun terjadi pada tahun 2021 dilansir dari laman kabar24.bisnis.com dikatakan bahwa Komisi Pemberantasan Korupsi memanggil Konsultan Pajak. Hal tersebut terjadi karena adanya konsultan pajak yang menerima hadiah atau janji terkait pemeriksaan pajak yang terjadi pada tahun 2016-2017 pada Ditjen Pajak untuk menutupi manipulasi perpajakan perusahaan. Berdasarkan fenomena-fenomena yang terjadi mengenai kecurangan yang dilakukan oleh konsultan pajak, maka disinilah diperlukannya keputusan etis untuk menimalisir kejadian rekayasa laporan pajak suatu perusahaan.

Peneliti sebelumnya Nur Hidayat (2019) melakukan penelitian yang sama dengan judul "Keputusan etis Konsultan Pajak dimana etika profesi, sifat maachiavelin dan kompetensi sebagai variabel independennya". Sejalan dengan penelitian dari Pitaloka dan Ardini (2017) bahwa persepsi pentingnya etika berpengaruh positif terhadap pengambilan keputusan etis Konsultan Pajak. Perbedaan penelitian ini dengan penelitian sebelumnya terletak pada variabel pendukung lainnya, waktu dan tempat penelitian. Penelitian ini dilaksanakan tahun 2020 dengan subjek penelitian adalah Konsultan Pajak di Surabaya. Adapun tujuan dari penelitian ini adalah:

\section{TINJAUAN PUSTAKA}

\subsection{Etika Profesi}

Menurut Wijaya (2019) "Etika profesi berarti suatu kebiasaan yang berlaku umum dalam organisasi profesi”. Indikator dari variabel etika profesi, tanggung jawab profesi, mengabdi kepada kepentingan masyarakat, objektivitas, adanya kaidah dan standar moral. Menurut Nur Hidayat (2019) yang juga berprofesi sebagai konsultan pajak, mengatakan bahwa seorang Konsultan Pajak yang memiliki etika profesi tinggi dan ketaatan pada kode etik profesi kecil kemungkinannya membuat keputusan yang salah dalam melakukan kegiatan profesi atau pengambilan keputusan etisnya. Menurut wood dalam Tjongari dan Widuri (2014) etika dapat didefinisikan sebagai suatu kumpulan standar dari kode etik yang mengarah pada perilaku moral dan pengambilan keputusan etis. Etika merupakan sebuah fondasi dasar bagi seseorang maupun kelompok dalam melakukan suatu tindakan. Etika memberikan paradigma bagi seseorang untuj melihat baik buruk atau benar salahnya suatu tindakan atau keputusan yang akan diambil.

\subsection{Kompetensi}

Menurut NCVQ National Council for Vocationa Qualification dalam

Sudarmanto (2018) "Kompetensi merupakan kemampuan menjalankan aktivitas 
dalam pekejaan. indikator dari variabel kompetensi adalah pengetahuan, keahlian dan sikap atau kepribadian. Kompetensi menurut Ikatan Konsultan Pajak Indonesia dalam Kurniawan dan Sadjiarto (2013) adalah bahwa setiap anggota harus menjalankan praktek profesionalnya sesuai dengan pengetahuan teknis dan sesuai dtandar profesi. Setiap konsultan pajak dilarang memberikan jasa profesionalnya yang tidak sesuai dengan kompetensi yang diperlukan dalam melaksanakan tugasnnya.

\subsection{Pengambilan Keputusan Etis}

(Fahmi, 2016:2) "Pengambilan keputusan adalah proses pelacakan masalah dari latar belakang masalah, penentuan masasalah hingga, pembentukan kesimpulan dan rekomendasi”. Indikator pengambilan keputusan etis adalah prinsip moral dan prinsip etika. Menurut Djatmiko dalam penelitian Tjongari dan Widuri (2014) mendefinisikan bahwa pengambilan keputusan sebagai proses pengambilan pilihan dari beberapa alternatif yang ada. Pengambilan keputusan etis ini berkaitankdengan faktor individu, yaitu terdiri dari pengetahuan, nilai individu, sikap dan niat serta karakteristik sosial seperti Pendidikan dan pengalaman.

\subsection{Hipotesis}

Menurut Sugiyono (2016) "hipotesis diartikan sebagai jawaban sementara terhadap rumusan masalah penelitian, dimana rumusan masalah penelitian telah dinyatakan bentuk kalimat pernyataan”. Dikatakan sementara, karena jawaban yang diberikan baru berdasarkan teori yang relevan, belum berdasarkan fakta-fakta empiris yang diperoleh melalui penelitian. Berdasarkan fenomena yang terjadi, maka hipotesis penelitian ini adalah diduga terdapat pengaruh antara Etika Profesi dan Kompetensi terhadap Pengambilan Keputusan Etis Konsultan Pajak Di Surabaya baik secara parsial maupun stimultan.

\section{METODE PENELITIAN}

\subsection{Teknik Pengumpulan Data}

Menurut Sugiyono (2012) dikatakan bahwa metode survey adalah metode yang digunakan untuk mendapatkan data dari suatu tempat tertentu yang alamiah atau bukan buatan, tetapi peneliti melakukan perlakuan dalam pengumpulan data, yaitu dengan mengedarkan kuesioner, test, wawancara terstruktur dan sebagainya (perlakuan tidak seperti dalam eksperimen). Teknik pengumpulan data adalah tentang siapa sumbernya, alat yang digunakan, dan cara pengumpulan data tersebut. Dalam penelitian ini, peneliti menggunakan data primer sebagai sumber data. Data Primer merupakan data yang diperoleh langsung dari sumber melalui kuesioner atau observasi. Penelitian ini menggunakan kuesioner sebagai bahan pengumpulan data. Kuesioner menggunakan kuesioner positif yang disebar langsung ke beberapa kantor Konsultan Pajak dan disebar melalui masing-masing email Konsultan Pajak di Surabaya.

\subsection{Populasi dan Sampel}

Populasi dalam penelitian ini adalah Konsultan Pajak di Surabaya yang terdaftar dalam IKPI (Ikatan Konsultan Pajak Indonesia) Cabang Surabaya. IKPI merupakan 
organisasi Konsultan Pajak terbesar di Indonesia. Penelitian ini menarik sampel sebesar 254 sampel. Penelitian ini menggunakan rumus slovin, dengan menggunakan rumus Slovin di atas dengan populasi 252 Konsultan Pajak di Surabaya dan dengan tingkat kesalahan 5\% maka diperoleh hasil sampel yang dibutuhkan sebesar 154 responden. Teknik sampling yang digunakan dalam penelitian adalah teknik random sampling dimana teknik ini memberikan peluang yang sama pada seluruh bagian populasi tanpa melihat kelas anggota populasi.

\subsection{Teknik Analisis Data}

\subsubsection{Uji Validitas}

Menurut (Ghozali, 2018:51) "Uji validitas digunakan untuk mengukur sah atau valid tidaknya suatu kuisioner. Suatu kuisioner dinyatakan valid jika pertanyaan pada kuisiner mampu untuk mengungkapkan sesuatu yang akan diukur oleh kuisioner tersebut”. Pada penelitian ini Uji Validitas digunakan untuk mengukur valid atau tidaknya kusioner yang diajukan kepada sampel penelitian.

\subsubsection{Uji Relibiltas}

Uji Reliabilitas digunakan untuk melihat apakah data yang digunakan itu andal atau tidak. Dengan Kriteria keputusan uji realibilitas sebagai berikut :

a. "Jika $\alpha>0.60$, maka instrumen tersebut bersifat reliabel."

b. "Jika $\alpha<0.60$, maka instrumen tersebut bersifat tidak reliabel."

\subsubsection{Uji Normalitas}

Menurut (Ghozali, 2016) "Uji normalitas dilakukan untuk menguji apakah dalam model regresi variabel independen dan variabel dependen atau keduanya mempunyai distribusi normal atau tidak. Apabila variabel tidak berdistribusi secara normal maka hasil uji statistik akan mengalami penurunan". Pengujian normalitas data ini menggunakan Test of Normality Kolmogorov-Smirnov dalam program SPSS. Dengan ketentuan sebagai berikut:

a. "Jika nilai signifikansi lebih besar atau sama dengan (>) 0,05, maka data tersebut berdistribusi normal."

b. "Jika nilai signifikansi lebih kecil $(<) 0,05$, maka data tersebut berdistribusi tidak normal."

\subsubsection{Analisis Korelasi Product Moment}

Menurut (Sugiyono, 2016) "Korelasi ini digunakan untuk mencari hubungan dan membuktikan hipotesis hubungan dua variabel bila data kedua variabel berbentuk interval atau ratio, dannsumber data dari dua variabel atau lebih tersebut adalah sama”.

Berikut rumus untuk menghitung analisis Korelasi Product Moment adalah:

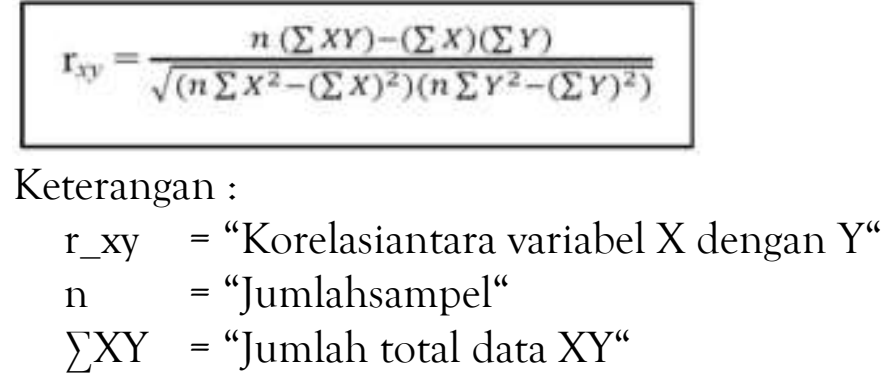


$\sum \mathrm{X}=$ "Jumlah total data variabel $\mathrm{X}$ "

$\sum \mathrm{Y}=$ "Jumlah total data variabel $\mathrm{Y}$ "

Tabel 1. Pedoman Untuk Memberikan Interpretasi Terhadap Koefisien Korelasi

\begin{tabular}{|l|l|}
\hline Interval Koefisien & Tingkat Hubungan \\
\hline $0,00-0,199$ & Sangat Rendah \\
\hline $0,20-0,399$ & Rendah \\
\hline $0,40-0,599$ & Sedang \\
\hline $0,60-0,799$ & Kuat \\
\hline $0,80-1,000$ & Sangat Kuat \\
\hline
\end{tabular}

\subsubsection{Uji Korelasi Ganda}

Menurut Sugiyono (2016) "Merupakan angka yang menunjukan arah dan kuatnya hubungan antara dua variabel independen secara bersama sama atau lebih dengan satu variabel dependen". Adapun variabel independen pada penelitian ini adalah etika profesi dan kompetensi.

\subsubsection{Koefsien Determinasi}

Menurut Sugiyono (2017) "Koefisien determinasi yang besarnya adalah kuadrat dari koefisien korelasi $\left(\mathrm{r}^{2}\right)$. Koefisien ini disebut koefisien penentu, karena varians yang terjadi pada variabel dependen dapat dijelaskan melalui varians yang tejadi pada variabel independen". Hasil dari uji ini berupa persentase.

"Rumus menghitung koefisien determinasi adalah: "

$$
K d=r^{2} \times 100 \%
$$

"Keterangan":

"Kd: Koefisien Determinasi"

" $\mathrm{r}$ : Koefisien Korelasi"

Koefisien determinasi tidak bernilai negatif atau paling besar sama dengan satu. Tingkat pengaruh koefisien determinasi dapat dilihat dari tabel pedoman interpretasi koefisien determinasi adalah sebagai berikut:

Tabel 2. Pedoman Interpretrasi Koefisien Determinasi

\begin{tabular}{|l|l|}
\hline Interval & Tingkat Pengaruh \\
\hline $0 \%-19,9 \%$ & Sangat Rendah \\
\hline $20 \%-39,9 \%$ & Rendah \\
\hline $40 \%-59,9 \%$ & Sedang \\
\hline $60 \%-79,9 \%$ & Kuat \\
\hline $80 \%-100 \%$ & Sangat Kuat \\
\hline
\end{tabular}

\subsubsection{Regresi Ganda}

Menurut Sugiyono (2016) "Analisis regresi linier berganda bermaksud meramalkan bagaimana keadaan (naik turunnya) variabel dependen (kriterium), bila dua atau lebih variabel independent, sebagai faktor-faktortprediator dimanipulasi (dinaik 
turunkan nilainya)". Jadi analisis regresi berganda akan dilakukan bila jumlah independennya minimal 2." Adapun persamaan regresi berganda sebagai berikut:

$$
\mathrm{Y}=\mathrm{a}+\mathrm{b}_{1} \cdot \mathrm{X}_{1}+\mathrm{b}_{2} \cdot \mathrm{X}_{2}
$$

$\mathrm{Y}=$ "Variabel Dependen"

$\mathrm{X}_{1}=$ "Variabel Independen" (1)

$\mathrm{X}_{2}=$ "Variabel Independen" (2)

$\mathrm{b} 1, \mathrm{~b} 2$, , "Koefisien regresi"

$\mathrm{a}=$ "Koefisien konstanta"

\section{$3.4 \mathrm{Uji} \mathrm{t}$}

Uji parsial digunakan peneliti untuk mengetahui pengaruh dari setiap variabel independen. Uji t dapat menunjukan hasil hipotesa parsial (melihat pengaruh masingmasing variabel X terhadap variabel Y" (Ghozali, 2018) . Adapum Rumus uji t ditunjukan dengan:

$$
t=\frac{r \sqrt{n-2}}{\sqrt{1-r^{2}}}
$$

Keterangan

$\mathrm{n}$ : jumlah data $\mathrm{r}$ : koefisien korelasi

Kriteria Pengukuran uji t :

Ho ditolak, Ha diterima apabila t hitung $>\mathrm{t}$ tabel

Ho diterima, Ha ditolak apabila thitung $<\mathrm{t}$ tabel

Teknik pengujian menggunakan teknik satu arah dengan asumsi hasil penelitian sudah diketahui memiliki kecenderungan positif terhadap suatu karakteristik.

\subsection{Uji F}

"Uji pengaruh bersama-sama (joint) digunakan untuk mengetahui apakah variabel independen secara bersama-sama atau joint mempengaruhi variabel dependen (Ghozali 2018:99)".

$$
\begin{aligned}
& F_{h}=\frac{R^{2} / k}{\left(1-R^{2}\right) /(n-k-1)} \\
& \text { Di mana: } \\
& R \text { : koefisien korelasi ganda } \\
& k \text { : banyaknya variabel independen } \\
& n: \text { banyakmya angeota sampel } \\
& \rightarrow \text { Konsultasikan dengan tabel } F \text {; dengan dk pembilang }=k \text { dan } d k \\
& \text { penyebut }=n-k-1 \text {. }
\end{aligned}
$$

\section{HASIL DAN PEMBAHASAN}

\subsection{Hasil Penelitian}

\subsubsection{Uji Validitas}

Berdasarkan analisis data yang dilakukan, hasil uji validitas menujukan data sebagai berikut ini: 
Tabel 3. Output SPSS (Validitas)

\begin{tabular}{|l|c|c|c|c|c|}
\hline Variabel & Pertanyaan & Koefisien Korelasi & $\mathbf{r}_{\text {tabel }}$ & $\mathbf{p}$-value & Keterangan \\
\hline \multirow{3}{*}{$\begin{array}{l}\text { Etika Profesi } \\
\text { X1) }\end{array}$} & $\mathrm{X} 1.1$ & $.833^{* *}$ & 0.135 & .000 & Valid \\
\cline { 2 - 6 } & $\mathrm{X} 1.2$ & $.847^{* *}$ & 0.135 & .000 & Valid \\
\cline { 2 - 6 } & $\mathrm{X} 1.3$ & $.833^{* *}$ & 0.135 & .000 & Valid \\
\cline { 2 - 6 } & $\mathrm{X} 1.4$ & $.852^{* *}$ & 0.135 & .000 & Valid \\
\hline \multirow{3}{*}{$\begin{array}{l}\text { Kompetensi } \\
\text { (X2) }\end{array}$} & $\mathrm{X} 2.1$ & $.900^{* *}$ & 0.135 & .000 & Valid \\
\cline { 2 - 6 } & $\mathrm{X} 2.2$ & $.933^{* *}$ & 0.135 & .000 & Valid \\
\cline { 2 - 6 } & $\mathrm{X} 2.3$ & $.903^{* *}$ & 0.135 & .000 & Valid \\
\hline $\begin{array}{l}\text { Keputusan Etis } \\
\text { (Y1) }\end{array}$ & $\mathrm{Y} 1.1$ & $.914^{* *}$ & 0.135 & .000 & Valid \\
\cline { 2 - 6 } & $\mathrm{Y} 1.2$ & $.886^{* *}$ & 0.135 & .000 & Valid \\
\hline
\end{tabular}

Hasil uji validitas pada tabel menunjukan bahwa seluruh data memiliki nilai p-value $(0,000)<0,05$. Adapun nilai koefisien korelasi ( $\mathrm{r}$ hitung) dari 9 item pertanyaan tersebut berkisar diantara 0,833 sampai dengan 0,933 dimana jika dibandingkan dengan nilai $r$ tabel $(\mathrm{DF}=154-2)$, $r$ hitung $>r$ tabel (nilai $r$ tabel adalah 0,1350 pada $\alpha$ $=0,05)$. Angka ini menunjukkan bahwa 9 item pertanyaan yang mewakili seluruh variabel pada pengujian ini adalah valid.

\subsubsection{Uji Reliabilitas}

Berdasarkan analisis data yang dilakukan, hasil uji reliabilitas menujukan data sebagai berikut ini :

Tabel 4 Output SPSS (Relibilitas)

\begin{tabular}{|c|c|c|c|c|}
\hline Variabel & $\begin{array}{l}\text { Item } \\
\text { Pertanyaan }\end{array}$ & $\begin{array}{l}\text { Cronbach's Alpha if } \\
\text { Item Deleted }\end{array}$ & Cronbach's Alpha & Keterangan \\
\hline \multirow{4}{*}{$\begin{array}{l}\text { Etika Profesi } \\
\text { (X1) }\end{array}$} & $\mathrm{X} 1.1$ & $.829^{* *}$ & \multirow{4}{*}{0.862} & Reliabel \\
\hline & $\mathrm{X} 1.2$. & $.821^{* *}$ & & Reliabel \\
\hline & $\mathrm{X} 1.3$. & $.831^{* *}$ & & Reliabel \\
\hline & X1.4. & $.815^{* *}$ & & Reliabel \\
\hline \multirow{3}{*}{$\begin{array}{l}\text { Kompetensi } \\
(\mathrm{X} 2)\end{array}$} & X2.1. & $.869^{* *}$ & \multirow{3}{*}{0.898} & Reliabel \\
\hline & $\mathrm{X} 2.2$. & $.819^{* *}$ & & Reliabel \\
\hline & $\mathrm{X} 2.3$. & $.875^{* *}$ & & Reliabel \\
\hline \multirow{2}{*}{$\begin{array}{l}\text { Keputusan Etis } \\
\text { (Y1) }\end{array}$} & Y1.1. & - & \multirow{2}{*}{0.762} & Reliabel \\
\hline & Y1.2. & - & & Reliabel \\
\hline
\end{tabular}

Berdasarkan hasil statistik reliabilitas, didapatkan nilai Cronbach's Alpha pada variabel Etika Profesi (X1), Kompetensi (X2), dan KeputusaniEtis (Y) > 0,6 yaitu 0,862, 0,898, dan 0,762 maka dapat disumpulkan ketiga variabel penelitian dapat dikatakan reliabel.

\subsubsection{Uji Normalitas}

Berdasarkan analisis data yang dilakukan, hasil statistik Uji Normalitas menujukan angka sebagai berikut : 
Tabel 4 Output SPSS (Kolmogorov-Smirnov)

\begin{tabular}{|ll|l|}
\hline & & Unstandardized Residual \\
\hline $\mathrm{N}$ & & 154 \\
Normal Parameters & Mean & .0000000 \\
& Std. Deviation & 1.28267719 \\
Most Extreme Differences & Absolute & .062 \\
& Positive & .052 \\
& Negative & -.067 \\
Test Statistic & & .067 \\
Asymp.Sig (2-tailed) & & $0.87^{c}$ \\
\hline
\end{tabular}

Dari tabel One Sample Kolmogorov-Smirnov Test di atas, diketahui bahwa nilai Sig. $(0,087)>0,05$ maka dapat disimpulkan bahwa data berdistribusi normal."

\subsubsection{Korelasi Product Moment}

Berdasarkan analisis data yang dilakukan, hasil uji Korelasi Product Moment menujukan data sebagai berikut ini :

Tabel 5 Output SPSS (Correlations)

\begin{tabular}{|ll|l|l|l|}
\hline & & Etika_Profesi & Kompetensi & Keputusan_Etis \\
\hline Etika_Profesi & Pearson Correlation & 1 & .054 & $.189^{* *}$ \\
& Sig. (1-tailed) & & .252 & .009 \\
& $N$ & 154 & 154 & 154 \\
\hline Kompetensi & Pearson Correlation & .054 & 1 & $.206^{* *}$ \\
& Sig. (1-tailed) & .252 & & .005 \\
& $N$ & 154 & 154 & 154 \\
\hline Keputusan_Etis & Pearson Correlation & $.189^{* *}$ & $.206^{* *}$ & 1 \\
& Sig. (1-tailed) & .009 & .005 & \\
& $N$ & 154 & 154 & 154 \\
\hline
\end{tabular}

Hasil tabel korelasi diatas menunjukan bahwa variabel Etika Profesi (X1) didapatkan nilai Sig. sebesar 0,009 <0,05 dan nilai koefisien korelasi sebesar 0,189> 0,135 maka dapat dikatakan variabel Etika Profesi memiliki hubungan signifikan terhadap Keputusan Etis dengan kekuatan hubungan sebesar 0,189 yang dimana masuk ke dalam kategori sangat rendah. Pada variabel Kompetensi (X2) didapatkan nilai Sig. sebesar 0,005 < 0,05 dan nilai koefisien korelasi sebesar 0,206 0,133 maka dapat dikatakan variabel Kompetensi memiliki hubungan signifikan terhadap Keputusan Etis dengan kekuatan hubungan sebesar 0,206. Hasil tersebut menunjukan bahwa variabel kompetensi dan keputusan etis berada pada kategori rendah.

\subsubsection{Korelasi Ganda}

Berdasarkan analisis data yang dilakukan, hasil statistik Korelasi Ganda menujukan data sebagai berikut ini :

Tabel 6 Output SPSS (Korelasi Ganda)

\begin{tabular}{|c|c|c|c|c|c|c|c|c|c|}
\hline \multirow[t]{2}{*}{ Modal } & \multirow[t]{2}{*}{$\mathrm{R}$} & \multirow{2}{*}{$\begin{array}{l}\mathrm{R} \\
\text { Square }\end{array}$} & \multirow{2}{*}{$\begin{array}{l}\text { Adjusted } \\
\text { R Square }\end{array}$} & \multirow{2}{*}{$\begin{array}{l}\text { Std. } \\
\text { Error of } \\
\text { the } \\
\text { Estimate }\end{array}$} & \multicolumn{5}{|c|}{ Change Statistics } \\
\hline & & & & & $\begin{array}{l}\mathrm{R} \\
\text { Square } \\
\text { Change }\end{array}$ & $\begin{array}{l}\text { F } \\
\text { Change }\end{array}$ & df1 & $\mathrm{df} 2$ & $\begin{array}{l}\text { Sig. F } \\
\text { Change }\end{array}$ \\
\hline 1 & $.272 \mathrm{a}$ & .074 & .062 & 1.291 & .074 & 6.052 & 2 & 151 & .003 \\
\hline
\end{tabular}

a. Predictors: (Constant), Kompetensi, Etika_Profesi

b. Dependent Variable: Keputusan_Etis 
"Pada tabel dapat dilihat bahwa didapatkan nilai R sebesar 0,27. Hasil dari statistik ini menunjukan bahwaikedua variabel secara bersamaan memiliki hubungan yang positif terhadap variabel dependen dengan kekuatan hubungan yang terjadi sebesar 0,272 dan masuk ke dalam kategori rendah.

\subsubsection{Koefisien Determinasi}

Berdasarkan analisis data yang dilakukan, hasil uji Koefisien Determinasi menujukan data sebagai berikut ini:

Tabel 7 Output SPSS (Koefisien Determinasi)

\begin{tabular}{|c|c|c|c|c|c|c|c|c|c|}
\hline \multirow[t]{2}{*}{ Modal } & \multirow[t]{2}{*}{$\mathrm{R}$} & \multirow{2}{*}{$\begin{array}{l}\mathrm{R} \\
\text { Square }\end{array}$} & \multirow{2}{*}{$\begin{array}{l}\text { Adjusted } \\
\text { R Square }\end{array}$} & \multirow{2}{*}{$\begin{array}{l}\text { Std. } \\
\text { Error of } \\
\text { the } \\
\text { Estimate }\end{array}$} & \multicolumn{5}{|c|}{ Change Statistics } \\
\hline & & & & & $\begin{array}{l}\mathrm{R} \\
\text { Square } \\
\text { Change }\end{array}$ & $\begin{array}{l}\text { F } \\
\text { Change }\end{array}$ & df1 & $\mathrm{df2}$ & $\begin{array}{l}\text { Sig. F } \\
\text { Change }\end{array}$ \\
\hline 1 & $.272 \mathrm{a}$ & .074 & .062 & 1.291 & .074 & 6.052 & 2 & 151 & .003 \\
\hline
\end{tabular}

a. Predictors: (Constant), Kompetensi, Etika_Profesi

b. Dependent Variable: Keputusan_Etis

Hasil pengujian koefisien determinasi menunjukan nilai R-Square sebesar 0.074. Hasil ini menunjukkan bahwa proporsi pengaruh seluruh variabel independen (Etika Profesi (X1) dan Kompetensi (X2)) secara simultan (bersamaan) terhadap variabel dependen Keputusan Etis (Y) sebesar 7.4\% sedangkan sisanya $(100 \%-7.4 \%=9.6 \%)$ dipengaruhi oleh variabel lain yang tidak ada di dalam penelitian atau model regresi linier ini"

\subsection{UJI $\mathrm{t}$}

Berdasarkan analisis data yang dilakukan, hasil uji t (parsial) menujukan data sebagai berikut ini:

Tabel 8 Output SPSS (Uji t)

\begin{tabular}{|c|c|c|c|c|c|c|}
\hline \multirow[t]{2}{*}{ Model } & & \multicolumn{2}{|c|}{$\begin{array}{l}\text { Unstandardized } \\
\text { Coefficients }\end{array}$} & $\begin{array}{l}\text { Standardized } \\
\text { Coefficients }\end{array}$ & \multirow[t]{2}{*}{$\mathrm{t}$} & \multirow[t]{2}{*}{ Sig. } \\
\hline & & B & $\begin{array}{l}\text { Std. } \\
\text { Error }\end{array}$ & Beta & & \\
\hline 1 & $\begin{array}{l}\text { (Constant) } \\
\text { Etika_Profesi } \\
\text { Kompetensi }\end{array}$ & $\begin{array}{l}5.281 \\
.095 \\
0.99\end{array}$ & $\begin{array}{l}.790 \\
.042 \\
.040\end{array}$ & $\begin{array}{l}.179 \\
.196\end{array}$ & $\begin{array}{l}6.683 \\
2.277 \\
2.503\end{array}$ & $\begin{array}{l}.000 \\
.024 \\
0.13\end{array}$ \\
\hline
\end{tabular}

a. Dependent Variable: Keputusan_etis

Dari tabel diatas dapat diketahui bahwa:

1. Nilai Sig. Etika Profesi $(X 1)(0,024)<0,05$ dan nilai t hitung $(2,277)>$ t tabel $(1,6550)$, maka $\mathrm{H}_{0}$ ditolak dan $\mathrm{H}_{1}$ diterima. Angka ini menunjukan bahwa adanya pengaruh positif signifikan antara Etika Profesi (X1) terhadap Keputusan Etis (Y). Hal ini menjelaskan bahwa semakin tinggi nilai Etika Profesi (X1) maka nilai Keputusan Etis (Y) juga akan semakin tinggi.

2. Nilai Sig. Kompetensi $(X 2)(0,013)<0,05$ dan nilai t hitung $(2,503)>$ t tabel $(1,6550)$, maka $\mathrm{H}_{0}$ ditolak dan $\mathrm{H}_{1}$ diterima. Artinya ada pengaruh positif signifikan 
antara Kompetensi (X2) terhadap Keputusan Etis (Y). Hal ini menjelaskan bahwa semakin tinggi nilai Kompetensi (X2) maka akan semakin tinggi pula nilai Keputusan Etis (Y).

\subsection{UJI F}

Berdasarkan analisis data yang dilakukan, hasil uji $\mathrm{F}$ menujukan data sebagai berikut ini:

Tabel 9 Output SPSS (UJI F)

\begin{tabular}{|ll|l|l|l|l|l|}
\hline Model & & $\begin{array}{l}\text { Sum of } \\
\text { Squares }\end{array}$ & df & $\begin{array}{l}\text { Mean } \\
\text { Square }\end{array}$ & F & Sig. \\
\hline 1 & Regression & 20.178 & 2 & 10.089 & 6.052 & $: 002^{\mathrm{b}}$ \\
& Residu & 251.725 & 151 & 1.667 & & \\
\hline & Total & 271.903 & 153 & & & \\
\hline
\end{tabular}

a. Dependent Variable: Keputusan_etis

b. Predictors: (Constant), Kompetensi, Etika_Profesi

Pengujian uji F menunjukan angka nilai F hitung (6,052) lebih besar dari F tabel $\left(\mathrm{F}_{(0.05 / 2 / 151)}=3,06\right)$ dan nilai Sig. pada tabel nilainya $0,000<0,05$. Berdasarkan angka tersebut dapat disimpulkan bahwa model regresi linier yang diestimasi layak digunakan. Hal ini menjelaskan adanya pengaruh signifikan variable independen (Etika Profesi (X1) dan Kompetensi (X2) secara simultan (bersamaan) terhadap variable dependen Keputusan Etis (Y).

\subsection{PERSAMAAN LINIER BERGANDA}

Persamaan regresi linier berganda dalam penelitian ini adalah:

Keputusan Etis $=5,281+0,095^{*}$ Etika Profesi $+0,099^{*}$ Kompetensi

Berdasarkan persamaan di atas, dapat diketahui bahwa kedua variabel memberikan pengaruh signifikan terhadap Keputusan Etis (Y) dimana variabel Etika Profesi (X1) dan variabel Kompetensi (X2) memberikan pengaruh positif masingmasing sebesar 0,095 dan 0,099 setiap 1 perubahan nilai yang terjadi. Secara total,besar nilai perubahan yang diterima Keputusan Etis (Y) adalah sebesar 0,194 (0,095+0,099 $=0,194)$ setiap 1 perubahan nilai yang terjadi pada kedua variabel independen tersebut. Artinya setiap penambahan 1 nilai dari kedua variabel independen, baik Etika Profesi (X1) maupun Kompetensi (X2) maka Keputusan Etis (Y) akan bertambah sebesar 0,194 .

\subsection{PEMBAHASAN}

\subsubsection{Pengaruh Etika Profesi Terhadap Pengambilan Keputusan Etis Konsultan Pajak di Surabaya}

Berdasarkan hasil analisis penelitian dapat dikatakan bahwasanya etika profesi berpengaruh positif signifikan terhadap variabel dependen yaitu pengambilan keputusan etis diliat dari nilai $t_{\text {hitung }}$ yang lebih besar dari $t_{\text {tabel }}$. Nilai koefisien yang menunjukan angka positif menandakan bahwasannya semakin tinggi etika profesi Konsultan Pajak semakin tinggi pula pengambilan keputusan etis. Penelitian ini 
memiliki hasil yang sejalan dengan penelitian Dwiyanti (2018) yang menyatakan bahwa etika profesi adalah suatu poin penting bagi pengemban profesi. Teori etika profesi mengatakan kesadaran kepada etika profesi membuat seorang Konsultan Pajak lebih mendorong untuk mengambil keputusan etis sesuai dengan kode etik yang telah berlaku. Dalam penelitiannya dikatakan bahwa etika profesi berpengaruh signifikan positif terhadap pengambilan keputusan etis. Etika merupakan sebuah koridor sikap yang harus dimiliki seorang konsultan professional. Semakin baik pemahaman mengenai etika profesi konsultan pajak, siklus fraud triangle akan lebih terminimalisir. Kecurangan-kecurangan dalam berbagai kasus tentang perpajakan yang dilakukan oleh konsultan pajak diharapkan tidak pernah terjadi lagi dengan didukung pemahaman yang mendalam mengenai etika profesi seorang konsultan.

\subsubsection{Pengaruh Kompetensi Terhadap Pengambilan Keputusan Etis Konsultan Pajak di Surabaya}

Hasil analisis dari penelitian yang dilaksanakan menunjukan bahwa kompetensi berpengaruh positif signifikan terhadap variabel dependen pengambilan keputusan etis

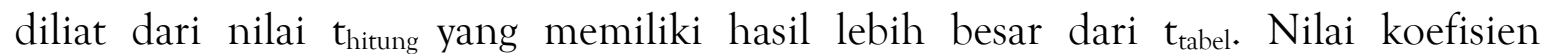
menunjukan angka positif, hasil tersebut menandakan bahwa semakin tinggi kompetensi Konsultan Pajak semakin tinggi pula pengambilan keputusan etis. Penelitian ini sejalan dengan penelitian Nur Hidayat (2019) yang mengatakan bahwasanya kompetensi berpengaruh positif signifkan terhadap pengambilan keputusan etis Konsultan Pajak yang mengatakan kompetensi suatu indikator penting dalam pengambilan keputusan etis. "Kompetensi ini berkaitan dengan kemampuan hardskill seseorang mengenai bidang ilmu pengetahuannya. Berdasarkan hasil penelitian ini kompetensi menjadi sangat penting dalam setiap proses pekerjaan konsultan pajak. Pengetahuan mengenai perpajakan yang di Indonesia sangat diperlukan konsultan pajak untuk menjadi pandai dalam bersikap dan menentukan sesuatu.

\subsubsection{Pengaruh Etika Profesi dan Kompetensi Terhadap Pengambilan Keputusan Etis Konsultan Pajak di Surabaya}

Dari hasil analisis penelitian yang telah dilaksanakan dapat disimpulkan bahwasanya variabel etika profesi dan kompetensi berpengaruh secara simultan terhadap pengambilan keputusan etis Konsultan Pajak di Surabaya dibuktikan dengan hasil uji $F$ memperoleh $f_{\text {hitung }}$ lebih besar daripada $f_{\text {tabel }}$. Berdasarkan hasil tersebut menunjukan bahwa hipotesis Ho ditolak dan Ha diterima. Menurut Hamid (2019) kompetensi sangat berpengaruh dalam pengambilan keputusan oleh seorang manajer trading semakin tinggi kompetensi seorang manajer maka akan semakin tinggi/besar juga manager mengabil keputusan yang menguntungkan begitu juga sebaliknya.

Hasil penelitian ini sejalan dengan Nur Hidayat (2019) dalam penelitiannya yang juga seorang Konsultan Pajak mengatakan "Bahwasannya seorang Konsultan Pajak yang memiliki etika profesi yang tinggi serta menjunjung tinggi kode etik profesi akan semakin kecil kemungkinan mengambil keputusan yang salah dalam menjalankan aktivitas profesinya, begitu juga dengan kompetensi yang tinggi maka Konsultan Pajak akan mengambil pekerja sesuai dengan kompetensinya dan lebih kecil kemungkin 
dalam pengambilan keputusan etis. Dalam penelitian Nur Hidayat (2019) ini etika profesi dan kompetensi berpengaruh secara simultan terhadap pengambilan keputusan etis Konsultan Pajak.”

Jadi dapat disimpulkan bahwa baik atau tidaknya etika profesi dan kompetensi seorang Konsultan Pajak akan berpengaruh terhadap pengambilan keputusan etis yang dilakukan oleh Konsultan Pajak itu sendiri. Semakin baik etika dan kompetensi seorang Konsultan Pajak maka akan semakin baik pula pengambilan keputusan etis Konsultan Pajak, sebaliknya semakin rendah etika profesi dan kompetensi seorang Konsultan Pajak maka semakin rendah juga pengambilan keputusan etis oleh Konsultan Pajak

\section{PENUTUP}

\subsection{Kesimpulan}

Berdasarkan hasil dari penelitian dan pembahasan ini maka bisa ditarik kesimpulan sebagai berikut:

1. Etika Profesi memiliki pengaruh signifikan terhadap pengambilan keputusan etis Konsultan Pajak di Surabaya.

2. Komptensi memiliki pengaruh signifikan terhadap pengambilan keputusan etis Konsultan Pajak di Surabaya.

3. Etika Profesi dan kompetensi memiliki pengaruh secara simultan terhadap pengambilan keputusan etis Konsultan Pajak di Surabaya.

\subsection{Saran}

Adapun saran yang dapat diberikan berdasarkan penelitian ini adalah sebagai berikut:

1. Pihak konsultan pajak hendaknya memahami etika profesi dan memahami batasan-batasan dalam tindakan yang diambil dengan tidak menyalahi aturan atau regulasi yang berlaku. Adanya sikap profesionalisme sebagai konsultan pajak akan memperkecil terjadinya penyelewengan dan manipulasi dalam pelaporan perpajakan. Konsultan pajak perlu mempertimbangkan baik buruknya dari setiap keputusan dan rekomendasinya sebagai profesi yang seharusnya lebih memahami arti penting pajak dalam sebuah negara.

2. Pihak Konsultan pajak sebaiknya memiliki kompetensi yang mumpuni dalam bidang perpajakan serta mengetahui seluruh peraturan perpajakan yang ada di Indonesia, agar ketidakpahaman yang menyebabkan kesalahan dalam proses perpajakan dapat dihindari. Sehingga keputusan yang diberikan kepada perusahaan klien dapat sesuai pada koridor yang tepat.

3. Bagi Peneliti selanjutnya dapat menambahkan variabel independen lainnya guna mendapatkan analisis mendalam seperti. Selain itu, perluasan subjek penelitian tidak hanya ruang lingkup kota Surabaya saja melainkan dapat meneliti kota besar lain yang memiliki banyak konsultan pajak. 


\section{DAFTAR PUSTAKA}

Alfons, M. 2019. December 12. DetikNews. Retrieved april 21, 2020, from M.Detik.com: m.detik.com/news/berita

Dahnur, H 2018, April 12. Kompas. Retrieved April 21, 2020, from Regional.Kompas.com: Regional.Kompas.com

Fahmi, I. 2016. Teori dan Teknik Pengambilan Keputusan Kualitatif dan Kuantitatif. Jakarta: PT RajaGrafindo Persada.

Ghozali, I. 2016. Aplikasi Analisis Multivariete IBM SPSS 23. Semarang: BPFE Universitas Diponogoro.

Kurniawan, Ciska, and Arja Sadjiarto. 2013. "Pemahaman Kode Etik Ikatan Konsultan Pajak Mengenai Hubungan Dengan Wajib Pajak Oleh Konsultan Pajak Di Surabaya." Tax E⿱ Accounting Review 1(1):55-62.

Ni Made, A. D., \& Kadek, T. D. 2018. Faktor Pengambilan Etis Oleh Konsultan Pajak: Individual dan Situsional.

Peraturan Menteri Keuangan Nomor 111/PMK.03/2014. Tentang Konsultan Pajak.

Pitaloka, Frigasari Dianing, and Lilis Ardini. 2017. "Analisis Faktor-Faktor Individual Dalam Pengambilan Keputusan Etis." Jurnal Ilmu Dan Riset Akuntansi 6(8):1-23.

Purba, J. M., \& Pujiastuti, S. E. 2016. Dilema Etik E Pengambilan Keputusan Etis. Jakarta: Buku Kedokteran.

Serevina, E. S., \& Hidayat, . 2019. The Effect of Ethics $\mathcal{E}$ Social Responsibility, Machiavvelin Character, $\mathcal{E}$ Competency On Ethical Decision Making of tax Consultant (Case of Tax Consultant in Bandung).

Sugiyono. 2016. Statistika untuk Penelitian. Bandung: ALFABETA Bandung.

Sugiyono. 2016. Metode Penelitian Kuantitatif Kualitataif Dan Kombinasi. edited by Alfabeta. Bandung: Alfabeta.

Tjongari, Fenny Veronica, and Retnaningtyas Widuri. 2014. "Analisis Faktor-Faktor Individual Yang Berpengaruh Terhadap Pengambilan Keputusan Etis Konsultan Pajak (Survey Pada Konsultan Pajak Di Jawa Timur).” Petra Christian University Tax and Accounting Review 4(2):1-7.

Wijaya, N. H., Fajar, S. A., Tjandra, C., \& Hendro, T. 2019. Etika Bisnis. Yogyakarta: Andi.

www.kabar.24.bisnis.com

www.kemenkeu.go.id 